\title{
Modeling the potential impacts of climate change on the water table level of selected forested wetlands in the southeastern United States
}

\author{
Jie Zhu ${ }^{1,2,3}$, Ge Sun ${ }^{4}$, Wenhong Li $^{3}$, Yu Zhang ${ }^{3}$, Guofang Miao ${ }^{5,6}$, Asko Noormets ${ }^{6}$, Steve G. McNulty ${ }^{4}$, \\ John S. King ${ }^{6}$, Mukesh Kumar ${ }^{3}$, and Xuan Wang ${ }^{1,2}$ \\ ${ }^{1}$ State Key Laboratory of Water Environment Simulation, School of Environment, Beijing Normal University, \\ Beijing 100875, China \\ ${ }^{2}$ Key Laboratory for Water and Sediment Sciences of the Ministry of Education, School of Environment, \\ Beijing Normal University, Beijing 100875, China \\ ${ }^{3}$ Nicholas School of the Environment, Duke University, Durham, North Carolina 27708, USA \\ ${ }^{4}$ Eastern Forest Environmental Threat Assessment Center, USDA Forest Service, Raleigh, \\ North Carolina 27606, USA \\ ${ }^{5}$ Department of Natural Resources and Environmental Science, University of Illinois at Urbana-Champaign, \\ Illinois 61801, USA \\ ${ }^{6}$ Department of Forestry and Environmental Resources, North Carolina State University, Raleigh, \\ North Carolina 27695, USA
}

Correspondence: Ge Sun (gesun@fs.fed.us) and Wenhong Li (wenhong.li@duke.edu)

Received: 11 April 2017 - Discussion started: 18 April 2017

Revised: 11 October 2017 - Accepted: 29 October 2017 - Published: 13 December 2017

\begin{abstract}
The southeastern United States hosts extensive forested wetlands, providing ecosystem services including carbon sequestration, water quality improvement, groundwater recharge, and wildlife habitat. However, these wetland ecosystems are dependent on local climate and hydrology, and are therefore at risk due to climate and land use change. This study develops site-specific empirical hydrologic models for five forested wetlands with different characteristics by analyzing long-term observed meteorological and hydrological data. These wetlands represent typical cypress ponds/swamps, Carolina bays, pine flatwoods, drained pocosins, and natural bottomland hardwood ecosystems. The validated empirical models are then applied at each wetland to predict future water table changes using climate projections from 20 general circulation models (GCMs) participating in Coupled Model Inter-comparison Project 5 (CMIP5) under the Representative Concentration Pathways (RCPs) 4.5 and 8.5 scenarios. We show that combined future changes in precipitation and potential evapotranspiration would significantly alter wetland hydrology including groundwater dynamics by the end of the 21 st century. Compared to the historical period, all five wetlands are predicted to become drier
\end{abstract}

over time. The mean water table depth is predicted to drop by 4 to $22 \mathrm{~cm}$ in response to the decrease in water availability (i.e., precipitation minus potential evapotranspiration) by the year 2100. Among the five examined wetlands, the depressional wetland in hot and humid Florida appears to be most vulnerable to future climate change. This study provides quantitative information on the potential magnitude of wetland hydrological response to future climate change in typical forested wetlands in the southeastern US.

\section{Introduction}

Wetlands provide ecosystem services such as groundwater recharge, water quality improvement, flood control, carbon sequestration, wildlife habitat, and recreation (Hammack and Brown, 2016; Richardson, 1994). The importance of water table level in regulating ecosystem function has long been recognized (Sun et al., 2000). Water table level controls biogeochemical cycles and emissions of greenhouse gases such as $\mathrm{CH}_{4}, \mathrm{CO}_{2}$, and $\mathrm{NO}_{x}$, and therefore has an influence on regional and global climate (Paschalis et al., 2017). A 
small change (less than $10 \mathrm{~cm}$ ) in wetland water table level may have profound impacts on wetland structure and other ecosystem functions (Webb and Leake, 2006).

The water table level of wetlands is strongly influenced by the variation and change in climate (Brooks, 2009; Fossey and Rousseau, 2016; Liu and Kumar, 2016), and continued regional wetland area losses are predicted in the United States and globally (House et al., 2016; Nicholls, 2004). The water table level of wetlands in the southeastern United States (SE US) may be particularly dynamic (Li et al., 2013; Sun et al., 2010). There are already indications of climate change in the SE US ( $\mathrm{Li}$ and $\mathrm{Li}, 2015$ ), and climate models project that temperature will increase by 2 to $10^{\circ} \mathrm{C}$ by 2100 in this region (Diffenbaugh and Field, 2013). The severity and patterns of storms are changing as well, with more heavy downpours in many parts of the SE US, and more intense Atlantic hurricanes (Wang et al., 2010; Wuebbles et al., 2014).

Various hydrological models, ranging from regression models to complex distributed models, have been used to study hydrological response to climate change. For example, the MIKE SHE physically based distributed model has been applied to forested wetlands in the SE US (Dai et al., 2010; Lu et al., 2009; House et al., 2016). The hydrological regime of wetland forests on the coastal plains of South Carolina was found to be highly sensitive to annual precipitation and temperature changes (Dai et al., 2010). The water table of pine flatwoods in Florida was predicted to be $20-40 \mathrm{~cm}$ lower than that of a baseline scenario when precipitation decreased by $10 \%$ or temperature increased by $2{ }^{\circ} \mathrm{C}(\mathrm{Lu}$ et al., 2009).

Integrated studies on the impacts of climate change on multiple wetlands in the SE US are limited. Physically based hydrological models provide a refined understanding of hydrologic processes (Yu et al., 2015; Chen et al., 2015) and quantification of hydrologic states and fluxes (Qu and Duffy, 2007; Shen and Phanikumar, 2010). However, these models are generally data (Bhatt et al., 2014) and computation intensive (Vivoni et al., 2011), and their potential uses are often undercut by equifinality of parameters (Beven, 1993; Kumar et al., 2013; Pokhrel et al., 2008). Implementing distributed hydrologic models across multiple wetlands that cover a range of climatic, topographic, and management conditions is challenging due to the computational expense, lack of finescale input data, and difficulty in application for multiple sites (Grayson et al., 1992). Conversely, in spite of the weakness of assumption of static relationships between climate and hydrological response patterns in the future, statistical models have advantages of both high efficiency in computation and acceptable performance in modeling when applied over multiple sites. The performance of empirical models in climate change studies appears to be powerful when incorporating downscaled general circulation model (GCM) outputs (Sachindra et al., 2013; Li et al., 2016). For example, Li et al. (2016) used log-linear models for 21 rainfall stations and 7 hydrometric stations to predict hydrological drought. Green- berg et al. (2015) developed an empirical model and demonstrated its utility for climate-change planning by forecasting the weekly hydrologic regimes from 2012 to 2060 and examining the indirect impacts of climate change on biological diversity.

In this study, five forested wetlands across a range of climatic/topographic gradients and different management conditions in the SE US were used to investigate the impact of future climate change on wetland hydrology (i.e., water table level). Future climate data from 20 GCMs participating in Coupled Model Inter-comparison Project 5 (CMIP5) under both Representative Concentration Pathways (RCPs) 4.5 and 8.5 scenarios were used. We hypothesized that the wetlands would become drier due to climatic warming and subsequent increases in evapotranspiration. We also hypothesized that hydrological responses would vary due to differences in baseline climate and wetland physical configurations.

The objectives of this study were to (1) construct and validate empirical models of wetland groundwater dynamics using long-term observational data in five typical southern forested wetlands; (2) forecast water table changes in the five wetlands under 40 climate change scenarios (i.e., $20 \mathrm{GCMs}$ and two $\mathrm{CO}_{2}$ emission pathways); and (3) investigate the key mechanisms driving the impacts of climate change in southern forested wetlands.

\section{Methods}

\subsection{Study area}

We selected five long-term research sites in the SE US representing five types of wetlands with different combinations of climate, topography, and anthropogenic management disturbances. These research sites include (1) an Alligator River National Wildlife Refuge bottomland hardwood wetland (designated as AR) on the coast of North Carolina, (2) a drained pocosin wetland covered by pine plantation forest (LP) on the lower coastal plain of North Carolina, (3) a cypress pond wetland (wetland FL-WET) in northern central Florida, (4) an upland slash pine forest (wetland FL-UP) in northern central Florida, and (5) a Carolina bay forest (SC) on the coastal plain of South Carolina (Fig. 1). The wetland characteristics (e.g., climate, soil, vegetation, wetland type classification) have contrasting features (Table 1). These wetlands were selected with the following considerations. AR (Miao, 2013) and LP (Noormets et al., 2010; Sun et al., 2010; Tian et al., 2015) are located in the lower coastal plain area of North Carolina within $100 \mathrm{~km}$ of one another, representing lower coastal plain forested wetlands with a similar climate and topography but different management conditions. AR is a natural coastal bottomland hardwood wetland with no tidal influence (Miao et al., 2013), while wetland LP is intensively managed by the forest industry for timber production (Manoli et al., 2016; Noormets et al., 2010; Sun et 


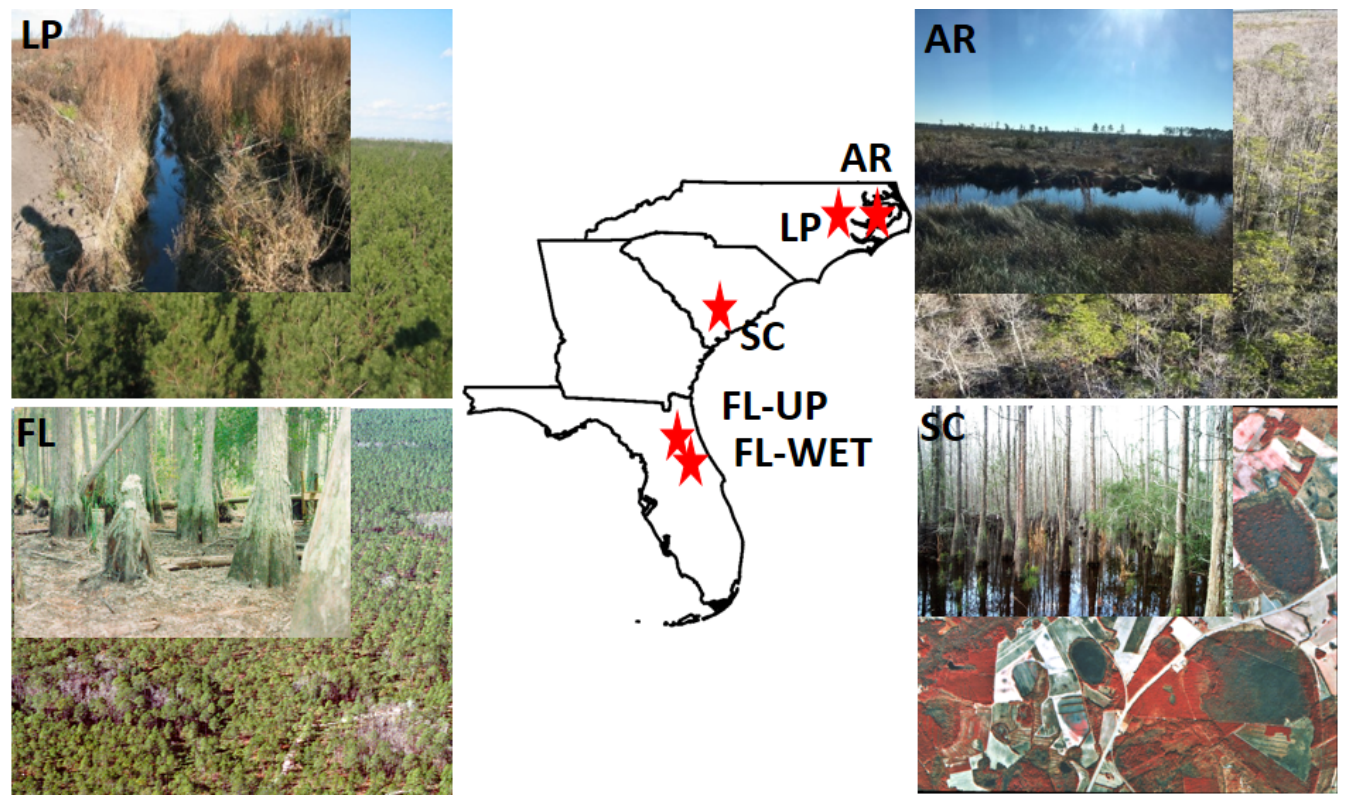

Figure 1. Study areas, where the star symbols mark the study site locations. Wetland AR: wetland of Alligator River National Wildlife Refuge in North Carolina; wetland LP: wetland of a loblolly pine plantation in North Carolina; wetland SC: wetland in South Carolina; wetlands in Florida: wetland FL-UP (upland in Florida) and FL-WET.

al., 2010). LP is located in the outer coastal plain mixed forest province of North Carolina. The area has been artificially drained with a network of field ditches $(90-100 \mathrm{~cm}$ deep; spacing $80-100 \mathrm{~m}$ ) and canals dividing the watershed into a mosaic of regularly shaped fields and blocks of fields (Sun et al., 2010). FL-WET and FL-UP (Lu, 2006; Lu et al., 2009) represent two types of ecosystems found in the same pine flatwood landscape with the same climate but slightly different elevation and management. FL-UP is dominated by slash pine (Pinus elliotii) plantation forests at a relatively high elevation, while FL-WET is dominated by naturally regenerated cypress (Taxodium distichum) in depressional areas in pine flatwoods. The FL research site is located $33 \mathrm{~km}$ northeast of Gainesville in Alachua County of northern central Florida. The SC wetland is located in Bamberg County, South Carolina, representing a typical depressional wetland in the region (Pyzoha et al., 2008; Sun et al., 2006). The SC wetland was covered by naturally regenerated deciduous trees (i.e., water oak, willow oak) and was surrounded by deep, well-drained sand dominated by hardwood plantations and agricultural crops (Pyzoha et al., 2008; Sun et al., 2006).

\subsection{Databases}

\subsubsection{Observed water table and meteorological data}

The data and the collection methods used in this study are summarized in Table 2 . The meteorological variables include precipitation, air temperature, wind speed, net radiation, and other canonical meteorological factors. The daylight duration data were from the United States Naval Observatory
(USNO). The dataset consists of $4882630 \mathrm{~min}$ time series observations for each variable (i.e., water table and meteorological variable) for AR, 2922 daily time series observations for LP, and 89121 daily time series future climate data for each variable from each GCM of all five sites. The $30 \mathrm{~min}$ air temperature was averaged at the daily scale for estimating the potential daily evapotranspiration using Hamon's equation (Federer and Lash, 1978a; Hamon, 1963):

$\mathrm{PET}_{H}=29.8 \times D \times \frac{e_{a}^{*}}{\mathrm{AT}+273.2}$,

where $\mathrm{PET}_{H}$ is potential daily evapotranspiration $\left(\mathrm{mm}\right.$ day $\left.^{-1}\right), D$ is day length $(\mathrm{h})$, and $e_{a}^{*}$ is the saturation vapor pressure $(\mathrm{kPa})$ at the daily mean air temperature $\left(\mathrm{AT},{ }^{\circ}\right)$ calculated by the equation modified from Dingman (2015):

$e_{a}^{*}=0.611 \times \exp \left(\frac{17.3 \times \mathrm{AT}}{\mathrm{AT}+237.3}\right)$.

A correction coefficient (Sun et al., 2002) was used to adjust PET calculated by Hamon's equation to better represent the forest PET for the study region. The correction coefficient for North Carolina ranged from 1.0 to 1.2 (Federer and Lash, 1978b), and was 1.3 for the Florida site (Sun et al., 1998). To be consistent and reduce uncertainty of PET estimates, 1.2 was used for all five wetlands in this study. 


\subsubsection{Future climate change data}

The daily mean climate data were derived from $20 \mathrm{GCMs}$, a product of the Multivariate Adaptive Constructed Analog (MACA) dataset (Supplement Table S1) for two future RCPs scenarios (RCPs 4.5 and 8.5; 2006-2099). Future climate data represent intermediate and high greenhouse gas (GHG) emission scenarios considering a historical climate forcing baseline (1950-2005) (Duan et al., 2016).

The GCM dataset was statistically downscaled from the CMIP5 model resolutions to either 4 or $6 \mathrm{~km}$ (Abatzoglou and Brown, 2012) (http://maca.northwestknowledge. net/index.php). The downscaled GCM climate dataset was determined to be a proper selection (i.e., $90 \%$ of the Perkins PDF - probability density function - skill score between 0.8 and 0.95 ) across the SE US by observed means and the entire distribution of observations (Keellings, 2016). We analyzed the historical and future climate conditions key to water table level, including the daily maximum near-surface $(2 \mathrm{~m})$ temperature, daily minimum near-surface $(2 \mathrm{~m})$ temperature, and daily precipitation from 1 January 1950 to 31 December 2099. Daily maximum and minimum air temperatures were averaged to derive daily air temperature (Klein Tank et al., 2002). Means from 20 GCM climate datasets were used. To analyze the historical and future hydroclimatic changes for the full timescale of the GCM simulations (i.e., 1950 2099), we selected three representative 20-year time periods according to IPCC Assessment Report 5 (2014). These time periods included the end of the 20th century (1980-1999) as a baseline, the future mid-21st century (2040-2059), and the end of the 21st century (2080-2099). Thus both the historical run and the future run share the same bias from the same GCM climate dataset. The five simulation scenarios include the following:

i. Baseline: baseline period 1980-1999;

ii. F1: RCPs 4.5 for the future period 2040-2059;

iii. F2: RCPs 4.5 for the future period 2080-2099;

iv. F3: RCPs 8.5 for the future period 2040-2059; and

v. F4: RCPs 8.5 for the future period 2080-2099.

\subsection{Model development}

We used a general regression model for this study by including climatic variables and water table depth 15 days prior to the modeled date that has major controls of wetland water balances. The fluctuations of the water table are a result of the water balance between inputs (i.e., precipitation $(P)$, groundwater and surface inflows) and outputs (i.e., outflow and evapotranspiration, ET). Therefore, we hypothesized that $P$ and ET fluxes and associated meteorological variables should largely control water table fluctuations. The lagged 15-day mean water table (i.e., the water table 15 days prior 
Table 2. Raw data summary.

\begin{tabular}{|c|c|c|c|c|c|c|}
\hline $\begin{array}{l}\text { Wetland } \\
\text { data types }\end{array}$ & & AR & LP & $\mathrm{SC}$ & FL-UP & FL-WET \\
\hline \multirow[t]{3}{*}{$\begin{array}{l}\text { Observation } \\
\text { data }\end{array}$} & $\begin{array}{l}\text { Meteorological } \\
\text { data } \\
\text { Interval }\end{array}$ & $\begin{array}{l}07 / 02 / 2009- \\
01 / 01 / 2011 \\
30 \mathrm{~min}\end{array}$ & $\begin{array}{l}\text { 01/01/2005- } \\
12 / 31 / 2012 \\
\text { Daily, with some } \\
\text { data missing }\end{array}$ & $\begin{array}{l}\text { 01/01/1997- } \\
\text { 12/31/2002 } \\
\text { Daily }\end{array}$ & $\begin{array}{l}\text { 01/01/1992- } \\
\text { 12/31/1996 } \\
\text { Daily }\end{array}$ & $\begin{array}{l}\text { 01/01/1992- } \\
31 / 12 / 1996 \\
\text { Daily }\end{array}$ \\
\hline & Water table data & $\begin{array}{l}03 / 19 / 2009- \\
12 / 31 / 2011\end{array}$ & $\begin{array}{l}01 / 01 / 2005- \\
12 / 31 / 2012\end{array}$ & $\begin{array}{l}01 / 01 / 1997- \\
12 / 31 / 2002\end{array}$ & $\begin{array}{l}01 / 01 / 1992- \\
12 / 31 / 1996\end{array}$ & $\begin{array}{l}\text { 01/01/1992- } \\
31 / 12 / 1996\end{array}$ \\
\hline & Interval & Daily & Daily & Daily & Daily & Daily \\
\hline \multirow[t]{3}{*}{ Validation data } & $\begin{array}{l}\text { Model } \\
\text { development year }\end{array}$ & 2009-2010 & 2009-2012 & $1997-2000$ & 1993-1994 & 1993-1994 \\
\hline & Validation year & 2011 & 2005-2008 & 2001-2002 & $\begin{array}{l}1992, \\
1995-1996\end{array}$ & $\begin{array}{l}1992, \\
1995-1996\end{array}$ \\
\hline & Interval & 15 days & 15 days & 15 days & 15 days & 15 days \\
\hline Prediction data & $\begin{array}{l}\text { Meteorological } \\
\text { data } \\
\text { Interval }\end{array}$ & $\begin{array}{l}01 / 01 / 1950- \\
12 / 31 / 2099 \\
30 \mathrm{~min}\end{array}$ & $\begin{array}{l}01 / 01 / 1950- \\
12 / 31 / 2099 \\
30 \mathrm{~min}\end{array}$ & $\begin{array}{l}01 / 01 / 1950- \\
12 / 31 / 2099 \\
30 \mathrm{~min}\end{array}$ & $\begin{array}{l}01 / 01 / 1950- \\
12 / 31 / 2099 \\
30 \mathrm{~min}\end{array}$ & $\begin{array}{l}01 / 01 / 1950- \\
12 / 31 / 2099 \\
30 \mathrm{~min}\end{array}$ \\
\hline References & $\begin{array}{l}\text { Data collection } \\
\text { methods }\end{array}$ & Miao et al. (2013) & $\begin{array}{l}\text { Noormets et } \\
\text { al. (2010), } \\
\text { Sun et al. (2010), } \\
\text { Tian et al. (2015) }\end{array}$ & Sun et al. (2006) & $\begin{array}{l}\text { Lu et al. (2009), } \\
\text { Sun et al. (2000) }\end{array}$ & $\begin{array}{l}\text { Lu et al. (2009), } \\
\text { Sun et al. (2000) }\end{array}$ \\
\hline
\end{tabular}

to the modeled date) was also considered as a potential explanatory variable following similar studies for hydroregime prediction (Greenberg et al., 2015; Webb et al., 2003), urban water demand prediction (Almendarez-Hernández et al., 2016; Arbués et al., 2004, 2010; Lyman, 1992), and energyfood-water interaction modeling (Liu et al., 2017; Ozturk, 2015). The adjustment's significance of minimizing heterogeneity in the traditional ordinary least squares assumptions was confirmed by including the first lagged dependent variable (Lyman, 1992; Ozturk, 2015). Additionally, the variance of the dependent variable does not change by introducing a proven wide-sense stationary $(|\beta|<1)$ first-order autoregressive process $\left(Y_{t}=\alpha+\beta Y_{t-1}+\varepsilon_{t}\right.$, where $\varepsilon_{t}$ is a white noise process with zero mean and constant variance $\sigma_{\varepsilon}^{2}$ ) (Mills, 1990). Also, the selected explanatory variables are considered to be independent.

Actual water loss from wetlands (ET) is controlled by both PET and precipitation (Sun et al., 2002). PET is mainly controlled by net radiation, air temperature, wind speed, and air humidity (Hargreaves and Samani, 1982). Due to data availability, this study used the air temperature-based Hamon equation to calculate PET (Hamon, 1963). Hamon's PET method has been widely used worldwide to estimate potential forest water use (Sun et al., 2002). Also, PET instead of air temperature was introduced into the model since PET was affected by not only air temperature, but also day length, which can better reflect variation in evaporative demand in different locations compared to air temperature alone.

The temporal scale for this study is 15 days, in line with criteria used by common wetland definitions. According to the US wetland regulatory standards, an area would be qual- ified as wetland when it is wet enough to be saturated within $1 \mathrm{ft}$ (i.e., $\sim 30 \mathrm{~cm}$ ) of the ground surface for 2 weeks or more during the growing season in most years (Tiner, 2016). In addition, it is suggested that the water of wetlands should be held in impoundments for at least 2 weeks to provide weed control and also to prolong wildlife use of habitat (Nelms, 2007). Thus, we set 15 days as the model time step, and all time series data were transformed to 15-day intervals.

Once all possible controlling variables were examined, we used correlation analysis and stepwise regression procedures to develop a parsimonious model for predicting wetland water table dynamics for each wetland. All explanatory variables were individually standardized first and introduced to the stepwise regression procedures to select the explanatory variables that were highly correlated with the modeled water table depth. The correlation analysis between any two of the selected explanatory variables was executed to distinguish paired collinearity. To reduce the multicollinearity, each of the paired collinear variables was removed by turns, and the other selected explanatory variables were then individually reintroduced to the stepwise regression procedures to seek a balance between the best statistical performance of the model and minimal multicollinearity of the explanatory variables (Sachindra et al., 2013). The correlation analysis and the stepwise regression model procedures were combined in this study to obtain an optimized model with the least number of variables and best statistical performance. Both the normality and the homoscedasticity for the five wetland sites were tested before the models were used for prediction. Also, the autocorrelation disturbance process was tested by Durbin's $h$ statistic (Bhargava et al., 1982). After the above tests and 
correlation analysis, the final model was chosen based on the coefficient of determination $\left(R^{2}\right)$ and probability $(P)$ value at a confidence level of $95 \%$. Data were separated into two groups that covered different periods for model development and validation (Table 2).

Limited data availability can contribute to model deficiency. Long-term, high-resolution observed wetland water table data for multiple sites in the SE US are rare. For example, the Alligator River National Wildlife Refuge bottomland hardwood wetland (AR site) is located in a remote location and water table data are the only measurements that characterize the local hydrological condition. Fortunately, the dataset covered both dry and wet years at the selected sites and was available for model development and validation. At the FL-UP and FL-WET wetlands, the time series including wet and dry years (1993-1994) were used to develop the model, and the remaining data (1992, 1995, and 1996) were used for model validation (Fig. 3). Then the model was applied to predict water table depth based on the GCM dataset (1950-2099), including the baseline period (1980-1999) and the future periods (2040-2059, 2080-2099).

The modeled future water tables were presented at annual and 15-day scales to better understand the variabilities of long-term averages and short-term extremes in water table dynamics. The modeled 15-day lowest water table data were further analyzed in two ways: (1) the percentage of time when the water table level is lower than $0 \mathrm{~cm}$, representing the likelihood of a wetland without surface water ponding, and (2) the percentage of time when the water table level was between 0 and $-30 \mathrm{~cm}$, representing the likelihood of saturated soil. This $30 \mathrm{~cm}$ definition was based on previous studies that suggested wetland soils have a $30 \mathrm{~cm}$ saturated fringe and that the average root depth is about $30 \mathrm{~cm}$ (Tiner, 2016). The $30 \mathrm{~cm}$ depth was also observed as the boundary "switch" for $\mathrm{CH}_{4}$ emission (Moore and Knowles, 1989), ammonification, denitrification (water table depth $<30 \mathrm{~cm}$ ), and nitrification (water table depth $>30 \mathrm{~cm}$ ) (Hefting et al., 2004).

\section{Results}

\subsection{Selected models and model performance}

The stepwise regression results suggest that the following linear model form best fits the water dynamics at all five wetlands:

$$
Y_{i t}=\alpha_{i 0}+\beta_{i 1} X_{1 t}+\gamma_{i 1} Y_{i t-1}+\varepsilon_{i t},
$$

where $X_{1 t}$ is the P-PET in mm per 15 days, $Y$ is the water table depth of wetland $i(i=1,2,3,4,5)$ in $\mathrm{cm}$ at time $t$, and $t$ and $t-1$ are the current and previous time steps, respectively. The residual plots and the normal probability plot of residuals showed normality and homoscedasticity for all five specific models. Durbin's $h$ statistic showed that all five wetland regressions support the autocorrelation disturbance
Table 3. Results for regressions of the water table for five wetlands in the SE United States.

\begin{tabular}{lrrrrr}
\hline Wetland & $\alpha_{i 0}$ & $\beta_{i 1}$ & $\gamma_{i 1}$ & $R^{2}$ & $p$ \\
\hline AR $(i=1)$ & -1.24 & 0.1137 & 0.7698 & 0.81 & $<0.001$ \\
LP $(i=2)$ & -19.55 & 0.3750 & 0.8530 & 0.83 & $<0.001$ \\
FL-UP $(i=3)$ & -23.17 & 0.3963 & 0.7206 & 0.69 & $<0.001$ \\
FL-WET $(i=4)$ & -1.36 & 0.2360 & 0.8707 & 0.78 & $<0.001$ \\
SC $(i=5)$ & -3.79 & 0.1454 & 0.8164 & 0.72 & $<0.001$ \\
\hline
\end{tabular}

Note: $i$ is the number of the wetlands, $i=1,2,3,4,5, t$ denotes the time periods, $\alpha_{i 0}$ is the intercept estimate, $\beta_{i n}$ is the coefficient estimate of the variable $X_{n}$ of the $i$ wetland, $\gamma_{i 1}$ is the coefficient estimate of the antecedent water table at $t-1$ time step of the $i$ wetland, $R^{2}$ is the coefficient of determination, and $p$ is the associated probability value.

process. The predicted water tables matched the observations consistently for all five wetlands, with the determination coefficient $\left(R^{2}\right.$, the proportion of the variance in the predicted water table depth) values ranging from 0.69 to 0.83 (Fig. 2). The statistics and parameter values for the five wetlands varied (Table 3). Among the five wetlands, $\beta_{i 1}$ and $\gamma_{i 1}$ were different but generally close, ranging from 0.11 to 0.40 and from 0.77 to 0.87 , respectively (Table 3 ). This suggests there are some site-specific differences, but the influence of P-PET and the antecedent water table at the $t-1$ time step on the modeled water table at the $t$ time step was similar across the study sites. However, the intercepts $\alpha_{i 0}$ did vary significantly, with a maximum of 23.2 (FL-UP) and a minimum of -1.2 (AR), indicating that there may be other site-specific factors that could vary across different wetlands but that are not explicitly included in the model as explanatory variables.

The statistical models were then validated using independent subsets of water table data during the validation period (Table 2, Fig. 3). The average water table was overpredicted by $1.4 \mathrm{~cm}$ for LP $(-106.25 \mathrm{~cm}$ for observation, $-104.85 \mathrm{~cm}$ for prediction, with a root mean square error (RMSE) of $4.92 \mathrm{~cm}$, similarly hereinafter), $0.95 \mathrm{~cm}$ for FL-WET $(19.02,19.97 \mathrm{~cm}$, with a RMSE of $9.23 \mathrm{~cm})$, and $1.3 \mathrm{~cm}$ for SC $(-19.1,-17.8 \mathrm{~cm}$, with a RMSE of $5.16 \mathrm{~cm})$. Also, it was underpredicted by $2.11 \mathrm{~cm}$ for FL-UP $(-48.97$, $-51.08 \mathrm{~cm}$, with a RMSE of $5.9 \mathrm{~cm}$ ) and $0.38 \mathrm{~cm}$ for AR $(-4.19,-4.57 \mathrm{~cm}$, with a RMSE of $3.71 \mathrm{~cm})$. The models captured the changing water table level even during an extremely dry year (e.g. 2007-2008 at LP). For the FL-WET, the water table levels were overpredicted in the normal period, while the observations and the predictions matched better during the dry year in 1993. Overall, the results show that the models performed reasonably well for all five wetlands, and could be used to predict future changes in water table level due to climate change.

\subsection{Projected patterns of future air temperature, PET, and precipitation}

The increase in the future mean annual air temperature under the RCPs 8.5 scenario, compared to the historic 1980 to 1999 baseline, is expected to be $3.9,4.3,4.0$, and $4.4^{\circ} \mathrm{C}$ in the fu- 

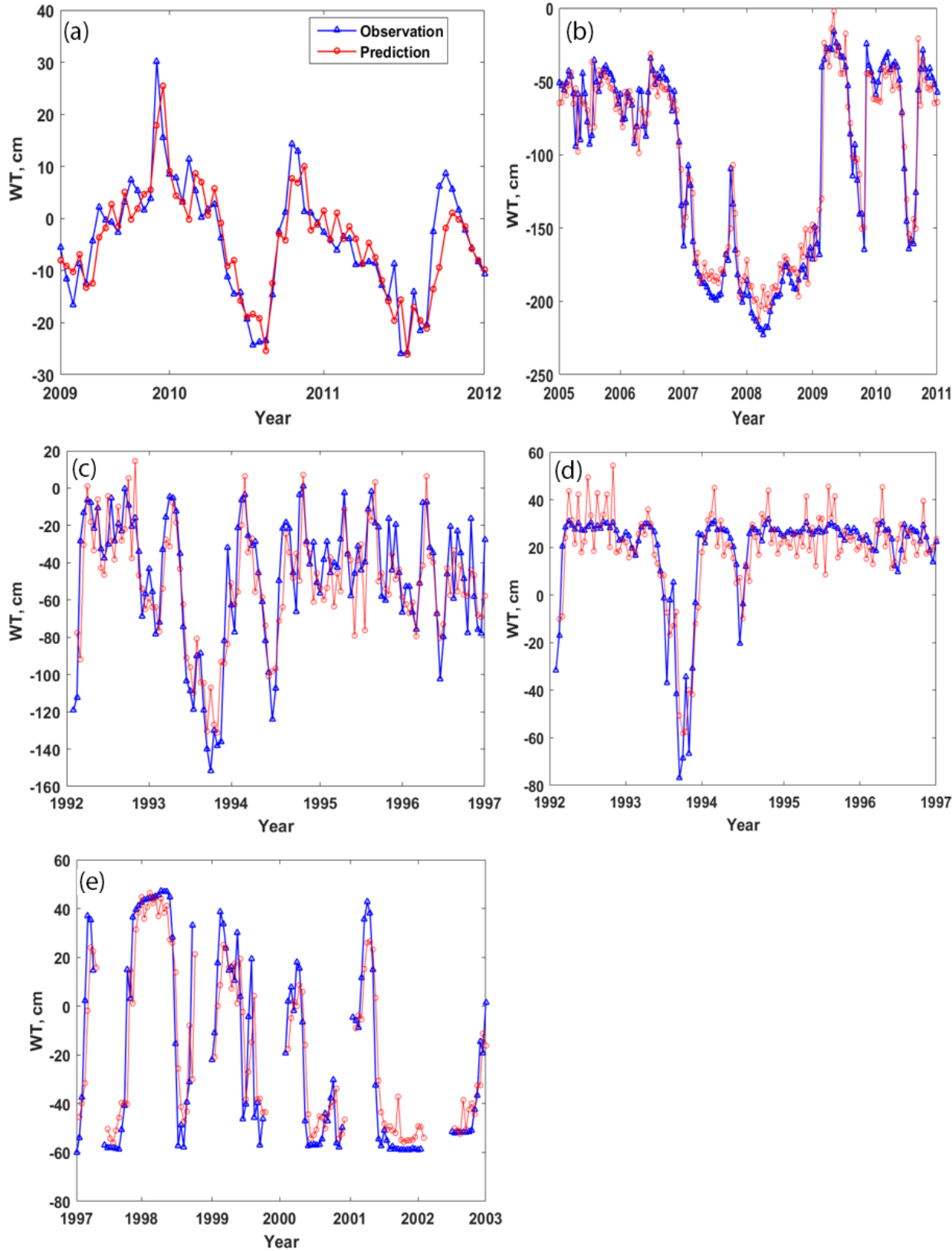

Figure 2. Comparison of observed and simulated mean water tables in five wetlands in the SE United States, where WT is the water table, (a) is site AR (Alligator River National Wildlife Refuge in North Carolina), (b) is site LP (loblolly pine plantation in North Carolina), (c) is site FL-UP (upland in Florida), (d) is site FL-WET (wetland in Florida), and (e) is site SC (wetland in South Carolina).

ture (2080 to 2099) for AR, LP, FL, and SC, respectively (Table 4, Fig. S1 in the Supplement). The average increase from the baseline under the RCPs 8.5 scenario in the five wetlands would be approximately $4^{\circ} \mathrm{C}$, which is consistent with the US climate assessment report (Pachauri et al., 2014). Future annual total PET would increase by $23 \%(221 \mathrm{~mm})$, $25 \%(238 \mathrm{~mm}), 23 \%(267 \mathrm{~mm})$, and $25 \%$ (266 mm) for AR, LP, FL, and SC, respectively, in the RCPs 8.5 scenario compared with that of the historical baseline period (Table 4). The increase in PET is expected to be smaller in the RCPs
4.5 scenario (Tables S2-S6, Fig. S2). For example, PET of wetland AR would increase by $13 \%(130 \mathrm{~mm})$ in the RCPs 4.5 scenario $(1107 \mathrm{~mm})$, while the increase would be $23 \%$ $(221 \mathrm{~mm})$ in the RCPs 8.5 scenario $(1198 \mathrm{~mm}$, Table S2).

The baseline mean annual precipitation was 1266,1275 , 1318, and $1192 \mathrm{~mm}$ (Tables S2-S6, Fig. S3) for AR, LP, FL, and $\mathrm{SC}$, respectively. The annual total precipitation under the RCPs 8.5 scenario would increase most in the wetland LP $(63 \mathrm{~mm})$ and $\mathrm{SC}(60 \mathrm{~mm})$ (Table 4$)$, which is nearly 2 times the increase in wetland AR $(37 \mathrm{~mm})$. In contrast, the annual 

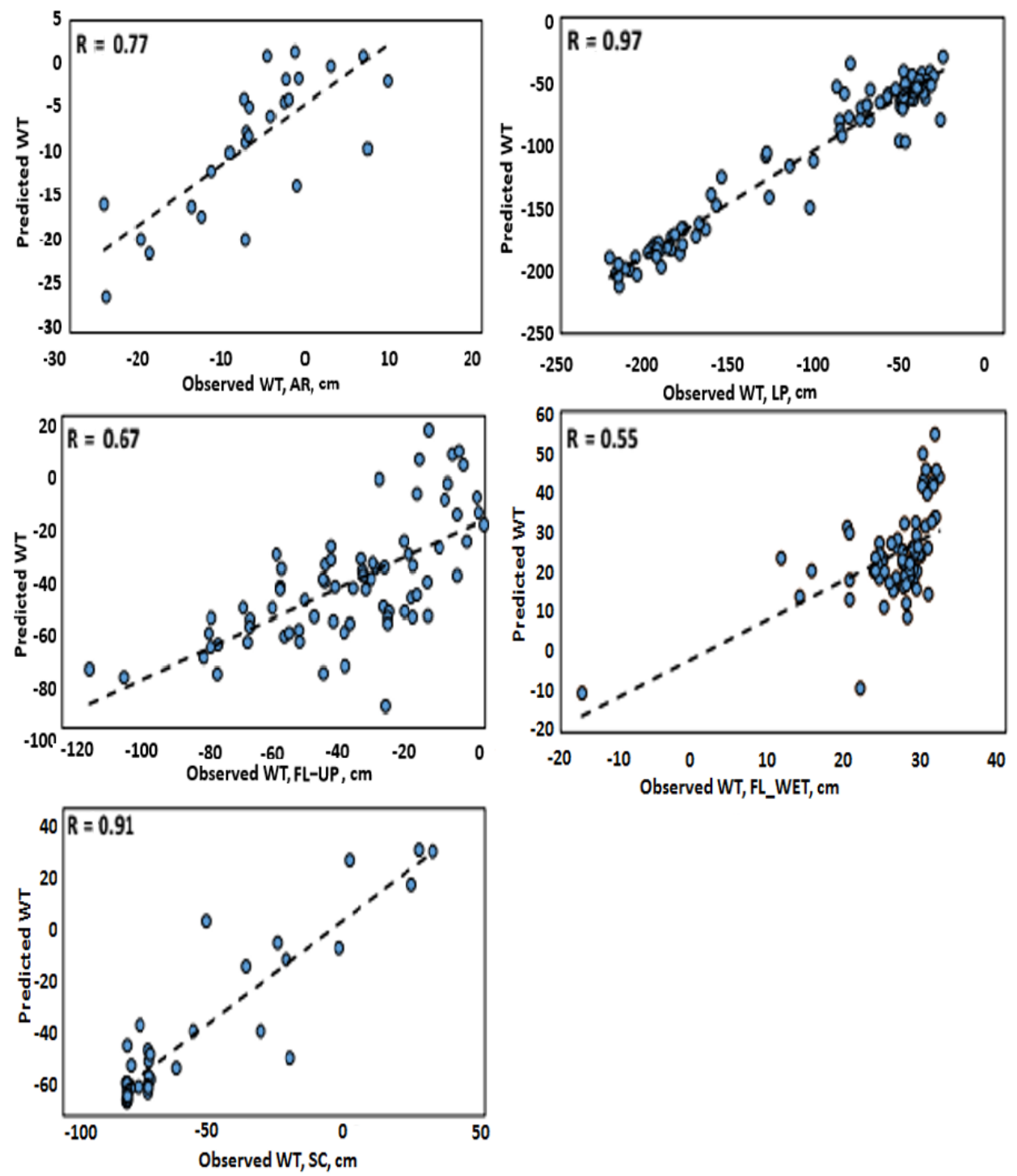

Figure 3. Scatter plots of the observed and predicted mean water tables in five wetlands in the SE United States (unit: $\mathrm{cm}$ ), where dashed lines are the trend line, and $R$ is the correlation coefficient between observed and predicted WT.

precipitation is projected to decrease at FL by $21 \mathrm{~mm}$ (Table 4). Unlike air temperature and PET, the magnitudes of the precipitation changes in the future RCPs 8.5 scenario were smaller than that of the RCPs 4.5 scenario (Tables S5-S6). Specifically, the precipitation would increase by 56,68 , and $70 \mathrm{~mm}$ (Tables S2-S4) under the RCPs 4.5 scenario for wetland $\mathrm{AR}, \mathrm{LP}$, and $\mathrm{SC}$, respectively.

The predicted PET will increase more than precipitation, causing a decrease in P-PET for all five wetlands. Specifically, the future annual mean P-PET under the RCPs 8.5 scenario would decrease by $64 \%$ (decrease by $184 \mathrm{~mm}$ from the $290 \mathrm{~mm}$ of the baseline), $56 \%$ (decrease by $175 \mathrm{~mm}$ from $313 \mathrm{~mm}$ ), $175 \%$ (decrease by $289 \mathrm{~mm}$ from $165 \mathrm{~mm}$ ), and $146 \%$ (decrease by $207 \mathrm{~mm}$ from $142 \mathrm{~mm}$ ) at AR, LP, FL, and SC, respectively (Fig. 4, Supplement Tables S1-S6). The decrease in P-PET is smaller under the RCPs 4.5 scenario. For example, the annual P-PET at AR would decrease by approximately $75 \mathrm{~mm}$ ( $26 \%$ of the baseline) under RCPs 4.5 and by $184 \mathrm{~mm}$ (64\% of the baseline) under RCPs 8.5 (Table S2).

\subsection{Future water table dynamics}

\subsubsection{Predicted annual water table}

This modeling analysis suggests that future climate change may considerably affect water table level. The annual average water table exhibits a decreasing trend in all five wetlands predicted by $20 \mathrm{GCMs}$ under both the RCPs 8.5 and RCPs 4.5 scenarios (Fig. 5). In AR, the mean water table will decrease by $4 \mathrm{~cm}$ from a long-term historical baseline period 
Table 4. Annual changes in variables from the baseline scenario to scenario RCPs 8.5 of five wetlands in the Se United States.

\begin{tabular}{lrrrrrr}
\hline Wetland & $\begin{array}{r}\text { WT changes } \\
(\mathrm{cm})\end{array}$ & $\begin{array}{r}\text { Baseline annual WT } \\
(\mathrm{cm})\end{array}$ & $\begin{array}{r}P \\
(\mathrm{~mm})\end{array}$ & $\begin{array}{r}\text { PET } \\
(\mathrm{mm})\end{array}$ & $\begin{array}{r}P \text { minus PET } \\
(\mathrm{mm})\end{array}$ & $\begin{array}{r}\text { AT } \\
\left({ }^{\circ} \mathrm{C}\right)\end{array}$ \\
\hline AR & -4 & 0 & 37 & 221 & -184 & 3.9 \\
LP & -19 & -100 & 63 & 238 & -175 & 4.3 \\
FL-UP & -17 & -73 & -21 & 267 & -289 & 4.0 \\
FL-WET & -22 & 2 & -21 & 267 & -289 & 4.0 \\
SC & -7 & -16 & 60 & 266 & -207 & 4.3 \\
\hline
\end{tabular}

Note: WT is water table, $P$ is precipitation, PET is potential evapotranspiration, and AT is air temperature.

Table 5. A summary of 15-day water table fluctuations in the growing season under the future RCPs 8.5 scenario of five wetlands in the SE United States.

\begin{tabular}{lrrrrr}
\hline Wetlands & $\begin{array}{r}\text { Lowest WT } \\
(\mathrm{cm})\end{array}$ & $\begin{array}{r}\text { PB of } \\
\text { no surface water }\end{array}$ & $\begin{array}{r}\text { PR85 of } \\
\text { no surface water }\end{array}$ & $\begin{array}{r}\text { PB of } \\
\text { saturated soil }\end{array}$ & $\begin{array}{r}\text { PR85 of } \\
\text { saturated soil }\end{array}$ \\
\hline AR & -17 & $49 \%$ & $62 \%$ & $100 \%$ & $100 \%$ \\
LP & -164 & $100 \%$ & $100 \%$ & $0 \%$ & $0 \%$ \\
FL-UP & -124 & $100 \%$ & $100 \%$ & $0 \%$ & $0 \%$ \\
FL-WET & -46 & $40 \%$ & $93 \%$ & $100 \%$ & $63 \%$ \\
SC & -42 & $100 \%$ & $100 \%$ & $100 \%$ & $57 \%$ \\
\hline
\end{tabular}

Note: WT is water table, PB is the probability in the baseline period, and PR85 is the probability during the RCPs 8.5 period (2080-2099, future scenario F4). The wetlands' ineffectiveness at storing surface water in this table was WT $<0 \mathrm{~cm}$ in 15 days, and the soil was considered saturated still for water table $>-30 \mathrm{~cm}$ in 15 days during the growing season.

mean of $0 \mathrm{~cm}$ depth (Table S2) compared to the future RCPs 8.5 scenario. The mean annual water table would decrease by $19 \mathrm{~cm}$ in LP (originally $-100 \mathrm{~cm}$, Table S3), by $7 \mathrm{~cm}$ in SC (originally $-16 \mathrm{~cm}$, Table S4), by $17 \mathrm{~cm}$ (originally $-73 \mathrm{~cm}$, Table S5) in FL-UP, and by $22 \mathrm{~cm}$ (originally $2 \mathrm{~cm}$, Table S6) in FL-WET.

\subsubsection{Predicted future 15-day water table}

At the 15-day and annual scale, the future water table would decline at all sites under the RCPs 4.5 scenario and especially the RCPs 8.5 scenario (Fig. 6). For AR, the decrease in the 15-day lowest water table would be $7 \mathrm{~cm}$, from $-10 \mathrm{~cm}$ of the historical baseline period to $-17 \mathrm{~cm}$ under the future RCPs 8.5 scenario (Fig. 6). The decrease for LP, SC, FL-UP, and FL-WET would be $28 \mathrm{~cm}$ (from $-135 \mathrm{~cm}$ ), $14 \mathrm{~cm}$ (from $-28 \mathrm{~cm}$ ), $23 \mathrm{~cm}$ (from $-101 \mathrm{~cm}$ ), and $27 \mathrm{~cm}$ (from $-19 \mathrm{~cm}$ ), respectively (Fig. 6).

Additionally, all the predicted 15-day water table levels were negative (i.e., water table $<0 \mathrm{~cm}$ ) at $\mathrm{LP}, \mathrm{FL}-\mathrm{UP}$, and $\mathrm{SC}$, meaning there would be no surface water ponding in the RCPs 8.5 scenario, as well as in the baseline scenario (Table 5, Fig. 6). In contrast, the wetlands AR and FL-WET show a lower probability (i.e., $40 \%$ for FL-WET, $49 \%$ for AR) with no surface water ponding in the baseline, but a significantly increasing probability of 62 and $93 \%$, respectively, in the RCPs 8.5 scenario.

Despite the fact that LP, FL-UP, and SC were all predicted to have no surface water (water table $<0 \mathrm{~cm}$ ) over the study period, the soil saturation status (water table depth still within $30 \mathrm{~cm}$ ) varied by location (Table 5). Sites LP and FL-UP would completely dry up by 2099 based on the RCPs 8.5 scenario. Wetland SC was saturated $100 \%$ of the time during the baseline period, but the saturation period would decrease to $57 \%$ by 2099 . Wetland FL-WET would be the most sensitive of the five sites. In FL-WET, the probability would increase most in losing surface water ponding (increasing from 40 to $93 \%$ from the baseline period to 2099) and decrease most in saturated soil (decreasing from 100 to $63 \%$ ). Notably, wetland AR would be the only one that would remain $100 \%$ saturated under all future scenarios, including the RCPs 8.5 scenario (Table 5, Fig. 6).

\section{Discussion}

\subsection{Difference and consistency of wetland hydrology models}

The lower $R^{2}$ values (0.69) of the model in the FL-UP site than in the FL-WET site (0.78) might be caused by other impacts beyond the model considerations, e.g., the hydrologic interaction between the uplands and the wetlands in the Florida site. Also, the temporal scale of 15 days may better capture the hydrological changes in FL-UP rather than FL-WET due to a faster drainage system in the FL-UP site. Further, different regression coefficients of climatic and hydrologic parameters (P-PET and the antecedent water table at 

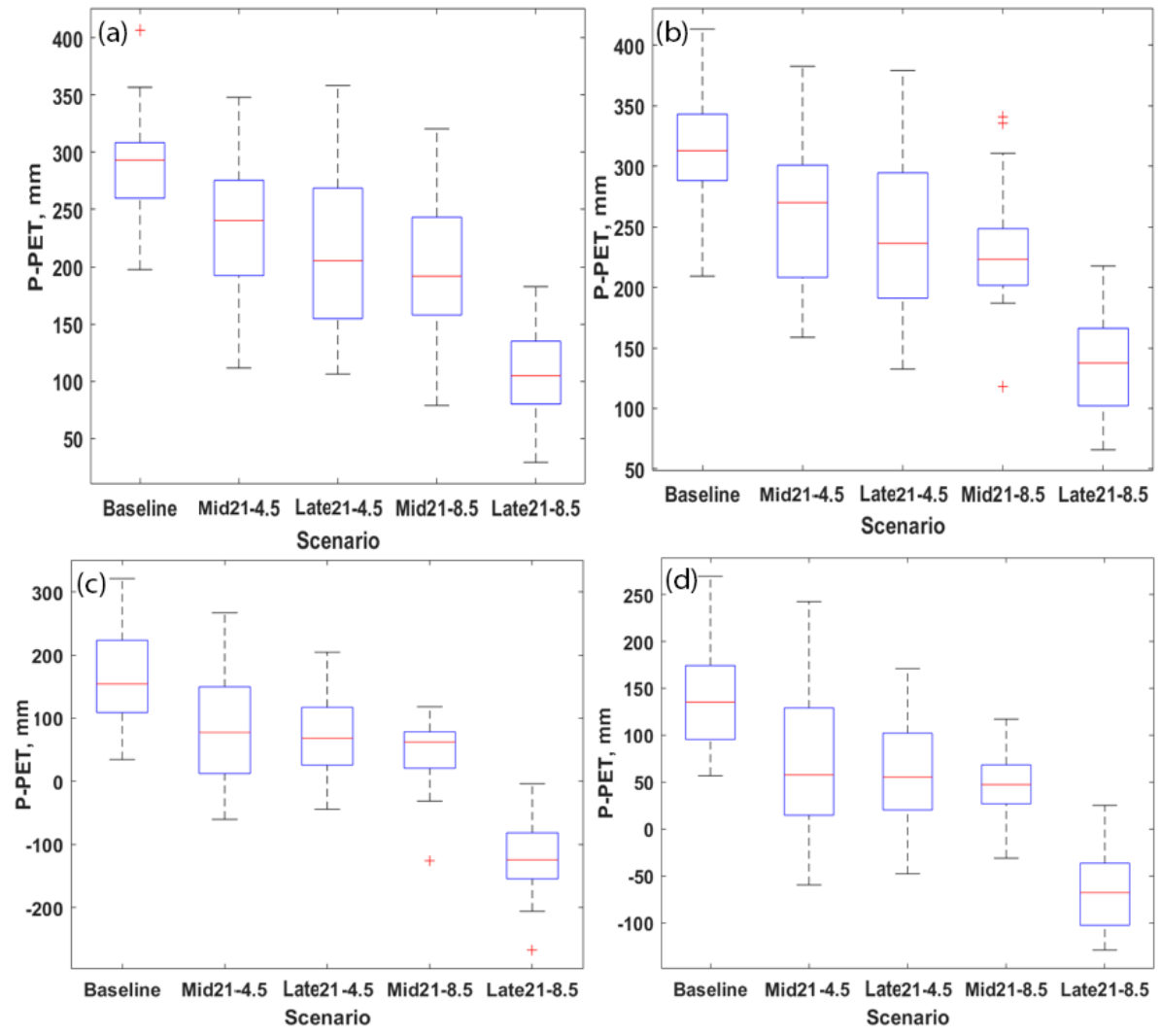

Figure 4. Total annual precipitation minus potential evapotranspiration of 20 GCMs in five wetlands in the SE United States (unit: mm), where (a) is site AR (Alligator River National Wildlife Refuge in North Carolina), (b) is site LP (loblolly pine plantation in North Carolina), (c) is site FL-UP (upland in Florida) and site FL-WET (wetland in Florida), and (d) is site SC (wetland in South Carolina). The baseline is 1980-1999, the historical run of GCMs; mid21 is 2040-2059, under the RCPs 4.5 and 8.5 scenarios; late21 is 2080-2099, under the RCPs 4.5 and 8.5 scenarios.

the $t-1$ time step) and different intercepts (Table 3) among the five wetlands indicate different major controls for each of the wetland types. For example, the model shows much lower (approximately 10 times) intercepts in wetland LP $(-19.55)$ and wetland FL-UP $(-23.17)$ compared to wetland FL-WET $(-1.36)$ and wetland SC $(-3.79)$. This is reasonable, given that both wetland FL-WET and wetland $\mathrm{SC}$ are depression wetlands, or geographically isolated wetlands (Tiner et al., 2016) (i.e., ponds within flat landscape) surrounded by uplands. Thus the wetlands would be wetter and ponded more frequently than uplands. However, site FLUP has sandy soils and would drain faster with the artificial ditching systems and higher elevation compared to FL-WET on a flat landscape. Hence, the much lower intercepts of site FL-UP and site LP may reflect the topographic and drainage management controls for these two wetland types.

\subsection{Differing controls on future water table level in different wetlands}

Although the statistical model follows a similar structure, i.e., including the same two explanatory variables in all five wetlands, and is proven to have good simulation performance overall, a closer comparison of the modeled water table levels among the five wetlands shows different climate influences. For example, the future annual water table depths under the RCPs 8.5 scenario decline the most in wetland FL. For the other three sites (AR, LP, and SC), this may be due to a large increase in PET. Moreover, the precipitation decreases in the wetland FL, while it increases at other sites.

Future changes in precipitation and PET are predicted to vary between AR and LP. In the RCPs 8.5 scenario, the increment of PET in LP is $8 \%$ higher than that in AR (Table 5), and the increment of precipitation in LP is $170 \%$ higher than that of AR. However, the change in P-PET is generally similar between the two wetlands (i.e., $-175 \mathrm{~mm}$ for LP and $-184 \mathrm{~mm}$ for AR, Supplement Table S2-S3). Despite the similar P-PET changes, the projected future water table depth changes in AR and LP are different. The mean water table depth of LP was predicted to decrease by $19 \mathrm{~cm}$ compared to $4 \mathrm{~cm}$, for AR from the period of 1980-1999 to 2080-2099. The differences are reflected by the different intercepts of the models, and may be due to the different management conditions in AR and LP. Wetland AR is a natu- 

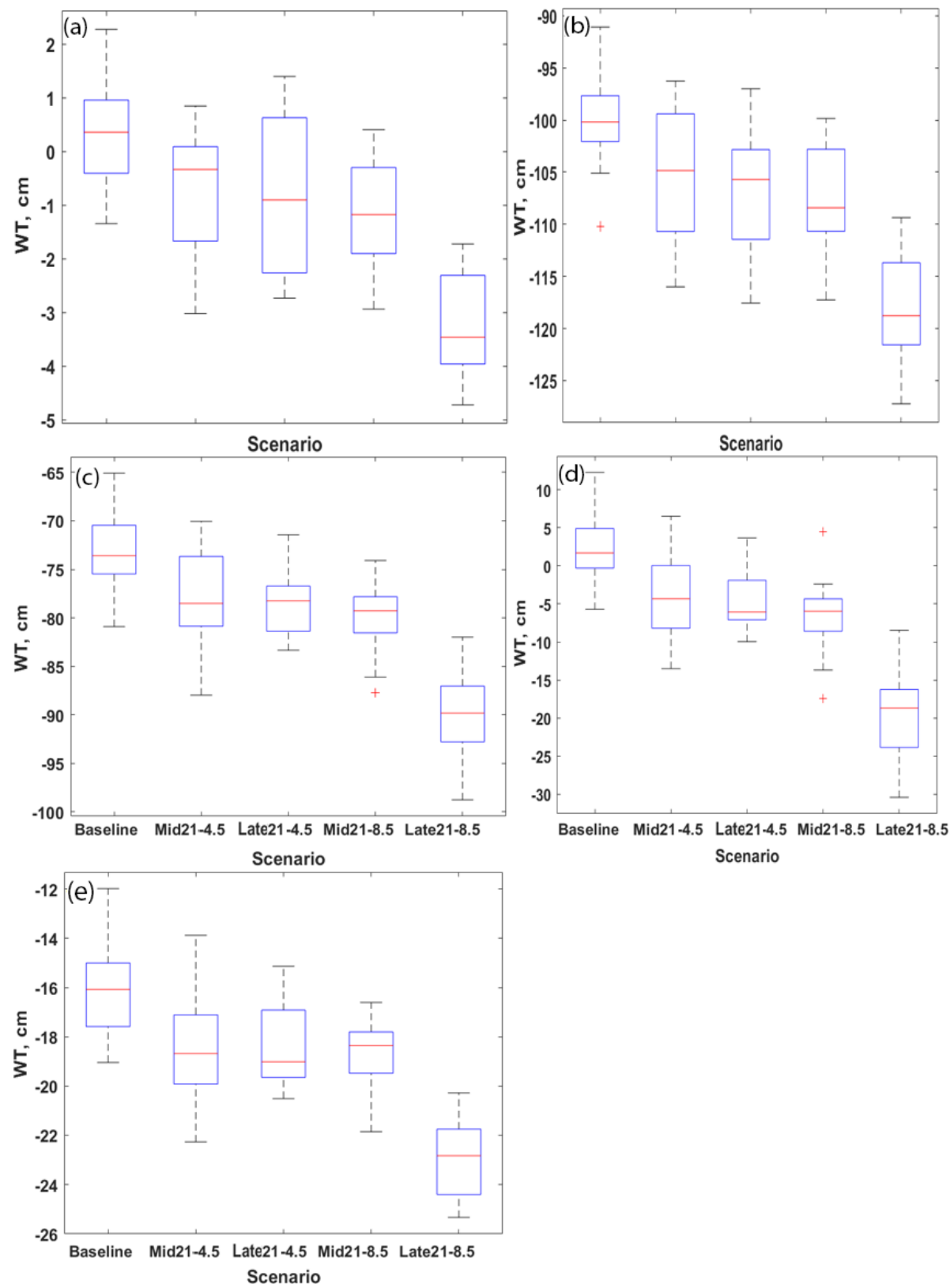

Figure 5. Mean predicted annual water table of 20 GCMs in five wetlands in the SE United States (unit: cm), where (a) is site AR (Alligator River National Wildlife Refuge in North Carolina), (b) is site LP (loblolly pine plantation in North Carolina), (c) is site FL-UP (upland in Florida), (d) is site FL-WET (wetland in Florida), and (e) is site SC (wetland in South Carolina). The baseline is 1980-1999, the historical run of GCMs; mid21 is 2040-2059, under the RCPs 4.5 and 8.5 scenarios; late21 is 2080-2099, under the RCPs 4.5 and 8.5 scenarios.

ral undisturbed natural bottomland hardwood swamp, while LP is highly managed pine plantation forest. LP has wellestablished ditches for drainage, with a flowline below the surface of the water table so that the hydraulic head of drains is lower than the hydraulic head of field water table depths. The drainage outflow of site LP from the watershed is closely related to the water table depth (Amatya et al., 2006). Additionally, in reality at the AR wetland, other local hydrologic drivers (not directly considered by the model, e.g., sea level rise) may increasingly slow the predicted decreasing water table depth. The sea level rise related hydrology may counter the predicted future water table decline.

Wetland type also contributes to the different water table dynamics. The water table changes differ from the baseline to the future RCPs 8.5 scenario for FL-WET and FLUP with the different topography conditions. The more significant change in FL-WET water table depth compared to the other site differences suggests that depressional wetlands 

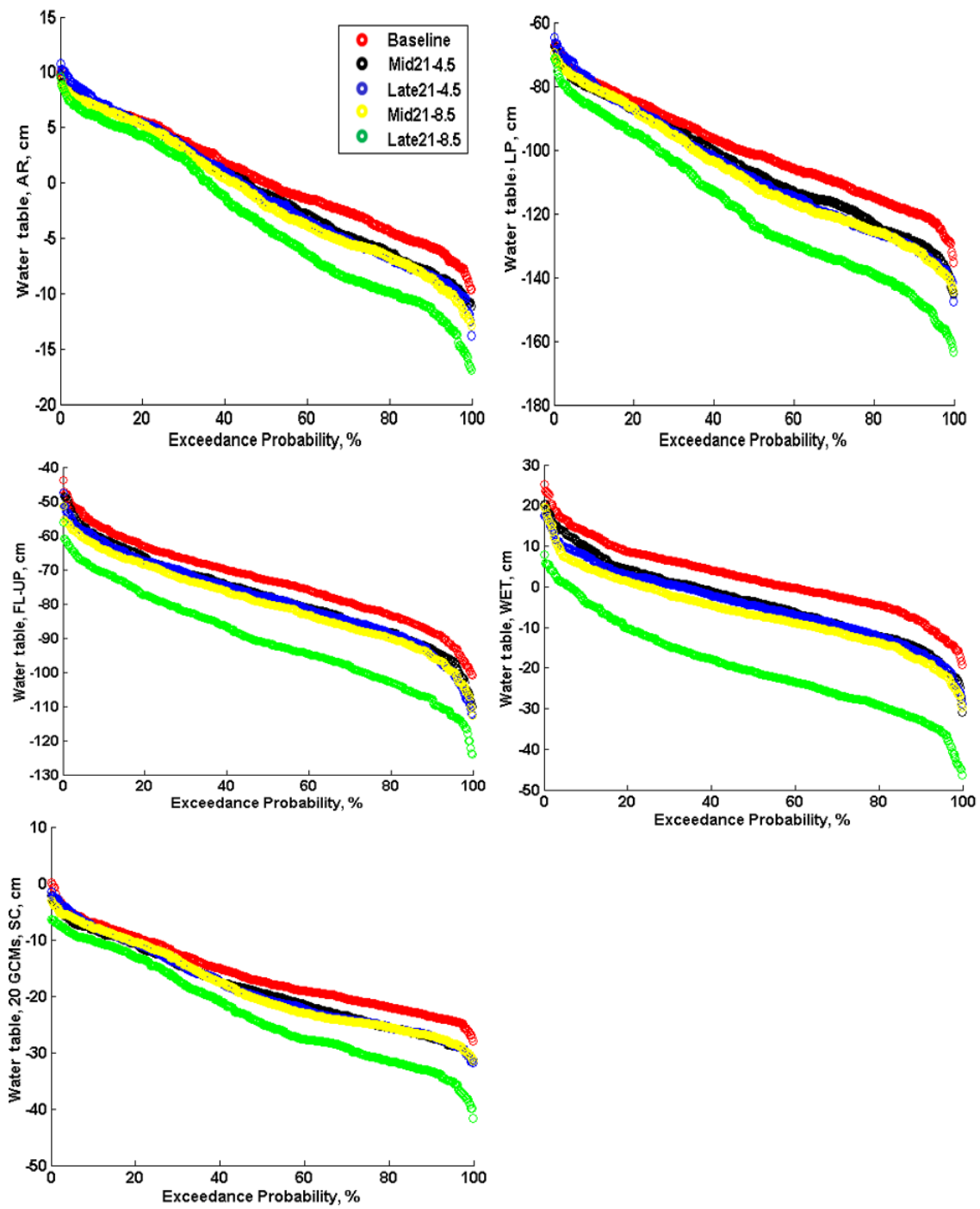

Figure 6. Exceedance probability of the mean predicted water table in the growing season of 20 GCMs in five wetlands in the SE United States (unit: $\mathrm{cm}$ ), where the baseline is 1980-1999, the historical run of GCMs; mid21 is 2040-2059, under the RCPs 4.5 and 8.5 scenarios; late21 is 2080-2099, under the RCPs 4.5 and 8.5 scenarios.

may be more sensitive to climate change compared to uplands, consistent with the results of $\mathrm{Lu}$ et al. (2009). Thus, the different responses of future water table depth in the wetlands modeled here, with varying climatic and topographic gradients and management practices, demonstrate the necessity and importance of developing wetland-specific hydrologic models.

\subsection{Implications}

\subsubsection{Efficient modeling of wetland water table dynamics}

Compared to a lumped (e.g., DRAINMOD-FOREST, Tian et al., 2015) or distributed parameter model (e.g., MIKE SHE, Lu et al., 2009), the empirical hydrological models developed in this study are simple. However, according to the model performance and results analysis in this study (Table 2, Figs. 2 and 3), our models were proven to be able to predict different water table dynamics well under a range of climatic and management conditions across the SE US region. Differences in wetland hydrological response to climate change suggest that different wetland management strategies should be developed according to individual site characteristics. For example, the differences between FL-UP and FL-WET suggest that depressional wetlands have higher sensitivity to climate change. The differences between AR and LP suggest the importance of integrating the mechanisms of water table response into sea level rise and extreme storm events. 
Overall, the empirical models developed from this study performed well at the site level, and can be incorporated into landscape and larger-scale biogeochemical models. For example, the empirical hydrological models can be linked with local soil respiration or regional methane emission models. Such an empirical approach should be compared to processbased hydrological models to effectively quantify the biogeochemical change under future climate.

\subsubsection{Biogeochemical cycles}

Previous studies report that 3 to $5^{\circ} \mathrm{C}$ increases in temperature and 146 to $192 \mathrm{~mm} \mathrm{yr}^{-1}$ increases in precipitation would lead to a $175 \%$ increase in the methane emissions (Shindell et al., 2004). The carbon (C) emissions in forested wetlands could be tightly linked (e.g., a logarithmic relationship) to drought or flood periods (Moore and Knowles, 1989). In the coastal wetland (AR) in this study, Miao et al. (2013) found that $93 \%$ of the annual average soil $\mathrm{CO}_{2}$ efflux of 960-1103 $\mathrm{g} \mathrm{C} \mathrm{m}^{-2}$ was released in non-flooded periods. Our study suggests that the non-flooded period would increase by $13 \%$ (from 49 to $62 \%$, assuming no influence in sea level rise) in the late 21 st century. This translates into a 116 to $133 \mathrm{~g} \mathrm{C} \mathrm{m}^{-2} \mathrm{CO}_{2}$ efflux increase by the end of the century for this site. Other studies suggest that gross ecosystem productivity and the available carbohydrate substrates for soil respiration would decrease with drought (Noormets et al., 2008). Wetland trees may also alter the use and allocation of nutrients (e.g., $\mathrm{N}$ cycling) in response to the changing availability of water (Vose et al., 2016).

\subsubsection{Droughts and wildfires}

The projected warming and future drying trends indicate an increasing threat of drought and wildfire in the study area (Mitchell et al., 2014). Plant distributions may shift due to drought (Desantis et al., 2007; Mulhouse et al., 2005), and trees may become increasingly susceptible to attack by pests and pathogens (Schlesinger et al., 2016). A warmer and longer growing season corresponds to an increased possibility of droughts and occurrence of wildland fires (Vose et al., 2016). Furthermore, increasingly frequent wildfire would release more carbon by biomass burning (Westerling et al., 2006) and stimulate other greenhouse gas (GHG) emissions (e.g., $\mathrm{CH}_{4}$ production) (Medvedeff et al., 2015). Thus, the management challenges in restoring wetland forests and reducing greenhouse gas emissions will substantially increase.

\subsubsection{Wildlife and habitat}

The predicted long-term drying of some sites (e.g., FLWET) may greatly affect the biological diversity and metapopulations of wetlands by impacting the inter-wetland movements, recruitment, recolonization, and genetic exchange of many species (Moor et al., 2015; Osland et al., 2013). Long-term drying could reduce the dispersion among wetlands, and increase the isolation of primarily aquatic species such as cricket frogs (Acris gryllus sp.), pig frogs (Lithobates grylio), swamp snakes (Seminatrix pygaea), and waterfowl (Greenberg et al., 2017; Davis et al., 2017; Murphy et al., 2016). The abundance of waterfowl was greater on impoundments than on seasonally flooded wetlands (Connor and Gabor, 2006). Changes in the water table depth of even less than $10 \mathrm{~cm}$ (predicted to decline from 7 to $28 \mathrm{~cm}$ among the studied wetlands) may have profound effects on habitat choice and species composition, and provide conditions which favor certain species or communities over those currently dominant in a given wetland (Reddy and DeLaune, 2008). Brent geese switch habitats within a water level span of $30 \mathrm{~cm}$ (Clausen, 2000). An equation linking the decay coefficient for a specific habitat type and the water table depth was illustrated in Bouma et al. (2014). A temperature increase of $2{ }^{\circ} \mathrm{C}$ (projected to be $4{ }^{\circ} \mathrm{C}$ in this study) in Florida would influence co-occurring mangrove and salt marsh plants (Coldren et al., 2016). This supports the hypothesis that wildlife habitats are at risk due to changing water table depth across the SE US.

\subsection{Uncertainty}

Although the models developed in this study are efficient for simulating the historic and future water levels at multiple wetlands, the models do not account for the full physical processes that govern wetland hydrological cycles. For example, an increase in atmospheric $\mathrm{CO}_{2}$ concentration is likely to increase plant water use efficiency and thus the ET and water balance of wetlands (Brummer et al., 2012). The empirical models do not explicitly simulate lateral water loss/gain from net groundwater flow (Johnston et al., 2005) and thus may cause simulation errors for certain wet periods. Thus, there is uncertainty regarding the hydrological response to extreme events such as extreme droughts or floods. In addition, wetlands are not isolated, and thus a landscape approach is needed to accurately model water table changes. Although water table dynamics are also affected by site-specific factors such as ditching/drainage, subsurface flow due to topographic differences, and local landscape hydrology, they were not considered explicitly as explanatory variables in our model. For example, in the AR wetland, future water table changes will also be impacted by the local hydrological change due to sea level rise (Miao, 2013). Our main objective was to evaluate the potential impacts of climate change on water table changes as forced primarily by changes in $\mathrm{P}$ and PET. We assume that the effects of other local site-specific factors are nonetheless taken into account indirectly by the coefficients (i.e., intercepts) of the models.

In addition to the uncertainty associated with hydrological model structure, there are uncertainties associated with future climate change data. The GCMs' precipitation or temperature projections are inherently inaccurate for small-scale studies, in spite of model bias corrections that have been 
implemented, and multiple models are used in this application. Compared to previous studies using hypothetical climate change data or climate data from a single GCM, our approach of assembling climate data from 20 GCMs and applying separate models to multiple wetlands represents perhaps a more robust way to project hydrological response. Hypothetical or stochastically generated climate conditions were used in most previous modeling studies (Chen et al., 2016). Climate data from a single GCM (Greenberg et al., 2015; Wang et al., 2015) have been used in wetland hydrological response modeling, but using several GCMs (Chen et al., 2012; Meinshausen et al., 2011) could provide a more realistic assessment. However, different GCMs and future scenarios produce very different climate projections. The differences are even greater when applied to localized areas (Alo and Wang, 2008). Multiple and overall GCM data may provide a better full-scale estimate of climate changes (Hessami et al., 2008).

\section{Conclusions}

The empirical models developed in this study are able to simulate water table level dynamics for different types of wetlands across the SE US. With the antecedent water table, precipitation, and potential evapotranspiration as the main predictors of water table level, the developed models are simple but powerful tools to provide useful water table change information under a range of climatic and management conditions. Under future climate change scenarios, the decrease in water availability is predicted to be a dominant factor for all five wetlands, resulting in a drier future (e.g., 4-22 cm of water table drops) in the study region, especially for isolated wetlands (e.g., the site in Florida) in the late 21st century. This study confirms the hypothesis that climate change may have a significant but varying influence on water table levels of different forested wetlands in the SE US.

Our study may serve as a basis for future regional studies to understand the interaction between water table level and climate and to quantify the role of wetlands in regulating regional water and energy balances. Also, the study results have important implications not only for wetland hydrology, but also wetland ecosystem management. The predicted hydrological changes have the potential to impact wetland biogeochemical cycles, fire regimes, and wildlife habitats. Further studies are needed to explore the physical mechanisms of how climate change affects wetland water table dynamics and associated ecological processes. Process-based ecohydrological models are needed to fully account for the impacts of climate change on vegetation dynamics and associated hydrological changes, and also to better understand the wetland-upland interactions and wetland-sea level rise interactions.
Data availability. The underlying research data from this manuscript can be accessed by email request to the corresponding author.

\section{The Supplement related to this article is available online at https://doi.org/10.5194/hess-21-6289-2017- supplement.}

Competing interests. The authors declare that they have no conflict of interest.

Special issue statement. This article is part of the special issue "Coupled terrestrial-aquatic approaches to watershed-scale water resource sustainability". It is not associated with a conference.

Acknowledgements. We would like to thank Heather Dinon Aldridge from NC State University for providing CMIP5 global climate model output. This study is supported by National Science Foundation grant AGS-1147608, the National Institute of Food and Agriculture, United State Department of Agriculture grants 2014-67003-22068 and 2011-67009-20089, and China Scholarship Council fellowship 2015-0604-0157. Partial support is provided by the Eastern Forest Environmental Threat Assessment Center, USDA Forest Service.

Edited by: Xuesong Zhang

Reviewed by: three anonymous referees

\section{References}

Abatzoglou, J. T. and Brown, T. J.: A comparison of statistical downscaling methods suited for wildfire applications, Int. J. Climatol., 32, 772-780, 2012.

Almendarez-Hernández, M., Avilés Polanco, G., Hernández Trejo, V., Ortega-Rubio, A., and Beltrán Morales, L.: Residential Water Demand in a Mexican Biosphere Reserve: Evidence of the Effects of Perceived Price, Water, 8, 428, https://doi.org/10.3390/w8100428, 2016.

Alo, C. A. and Wang, G. L.: Potential future changes of the terrestrial ecosystem based on climate projections by eight general circulation models, J. Geophys. Res.-Biogeo., 113, G01004, https://doi.org/10.1029/2007JG000528, 2008.

Amatya, D. M., Skaggs, R., and Gilliam, J.: Hydrology and water quality of a drained loblolly pine plantation in coastal North Carolina, Hydrology and Management of Forested Wetlands: Proceedings of the International Conference, St. Joseph, MI, American Society of Agricultural and Biological Engineers, 15-26, 2006.

Arbués, F., Barberán, R., and Villanúa, I.: Price impact on urban residential water demand: A dynamic panel data approach, Water Resour. Res., 40, W11402, https://doi.org/10.1029/2004WR003092, 2004. 
Arbues, F., Garcia-Valinas, M. A., and Villanua, I.: Urban Water Demand for Service and Industrial Use: The Case of Zaragoza, Water Resour. Manag., 24, 4033-4048, 2010.

Beven, K.: Prophecy, reality and uncertainty in distributed hydrological modeling, Adv. Water Resour., 16, 41-51, 1993.

Bhargava, A., Franzini, L., and Narendranathan, W.: Serial correlation and the fixed effects model, Rev. Econ. Stud., 49, 533-549, 1982.

Bhatt, G., Kumar, M., and Duffy, C. J.: A tightly coupled GIS and distributed hydrologic modeling framework, Environ. Modell. Softw., 62, 70-84, 2014.

Bouma, T. J., van Belzen, J., Balke, T., Zhu, Z. C., Airoldi, L., Blight, A. J., Davies, A. J., Galvan, C., Hawkins, S. J., Hoggart, S. P. G., Lara, J. L., Losada, I. J., Maza, M., Ondiviela, B., Skov, M. W., Strain, E. M., Thompson, R. C., Yang, S. L., Zanuttigh, B., Zhang, L. Q., and Herman, P. M. J.: Identifying knowledge gaps hampering application of intertidal habitats in coastal protection: Opportunities \& steps to take, Coast. Eng., 87, 147-157, 2014.

Brooks, R. T.: Potential impacts of global climate change on the hydrology and ecology of ephemeral freshwater systems of the forests of the northeastern United States, Climatic Change, 95, 469-483, 2009.

Brummer, C., Black, T. A., Jassal, R. S., Grant, N. J., Spittlehouse, D. L., Chen, B., Nesic, Z., Amiro, B. D., Arain, M. A., Barr, A. G., Bourque, C. P. A., Coursolle, C., Dunn, A. L., Flanagan, L. B., Humphreys, E. R., Lafleur, P. M., Margolis, H. A., McCaughey, J. H., and Wofsy, S. C.: How climate and vegetation type influence evapotranspiration and water use efficiency in Canadian forest, peatland and grassland ecosystems, Agr. Forest Meteorol., 153, 14-30, 2012.

Bullock, A. and Acreman, M.: The role of wetlands in the hydrological cycle, Hydrol. Earth Syst. Sci., 7, 358-389, https://doi.org/10.5194/hess-7-358-2003, 2003.

Chen, J., Brissette, F. P., and Leconte, R.: Coupling statistical and dynamical methods for spatial downscaling of precipitation, Climatic Change, 114, 509-526, 2012.

Chen, J., Brissette, F. P., and Zhang, X. C. J.: Hydrological Modeling Using a Multisite Stochastic Weather Generator, J. Hydrol. Eng., 21, https://doi.org/10.1061/(ASCE)HE.19435584.0001288, 2016.

Chen, X., Kumar, M., and McGlynn, B. L.: Variations in streamflow response to large hurricane-season storms in a Southeastern US watershed, J. Hydrometeorol., 16, 55-69, 2015.

Clausen, P.: Modelling water level influence on habitat choice and food availability for Zostera feeding Brent Geese Branta bernicla in non-tidal areas, Wildlife Biol., 6, 75-88, 2000.

Coldren, G., Barreto, C., Wykoff, D., Morrissey, E., Langley, J. A., Feller, I., and Chapman, S.: Chronic warming stimulates growth of marsh grasses more than mangroves in a coastal wetland ecotone, Ecology, 97, 3167-3175, 2016.

Connor, K. J. and Gabor, S.: Breeding waterbird wetland habitat availability and response to water-level management in Saint John River floodplain wetlands, New Brunswick, Hydrobiologia, 567, 169-181, 2006.

Dai, Z., Trettin, C. C., Li, C., Amatya, D. M., Sun, G., and Li, H.: Sensitivity Of Stream Flow And Water Table Depth To Potential Climatic Variability In A Coastal Forested Watershed, J. Am. Water Resour. As., 46, 1036-1048, 2010.
Davis, C. L., Miller, D. A. W., Walls, S. C., Barichivich, W. J., Riley, J. W., and Brown, M. E.: Species interactions and the effects of climate variability on a wetland amphibian metacommunity, Ecol. Appl., 27, 285-296, 2017.

Desantis, L. R. G., Bhotika, S., Williams, K., and Putz, F. E.: Sealevel rise and drought interactions accelerate forest decline on the Gulf Coast of Florida, USA, Glob. Change Biol., 13, 2349-2360, 2007.

Diffenbaugh, N. S. and Field, C. B.: Changes in Ecologically Critical Terrestrial Climate Conditions, Science, 341, 486-492, 2013.

Diggs, J. A.: Simulation of nitrogen and hydrology loading of forested fields in eastern North Carolina using DRAINMOD-N II, MS thsis, North Carolina State University, Raleigh, 2004.

Dingman, S. L.: Physical hydrology, Waveland press, 2015.

Dow, K., Carter, L., Brosius, A., Diaz, E., Durbrow, R., Evans, R., Fauver, S., Hayden, T., Howard, B., Jacobs, K., Landers, G., McNulty, S., Nicholson, J., Quattrochi, D., Rimer, L., Shuford, S., Stiles, S., and Terando, A.: Climate of the Southeast United States Variability, Change, Impacts, and Vulnerability, Washington, DC, Island Press, chap. 13, 295-320, 2013.

Duan, K., Sun, G., Sun, S. L., Caldwell, P. V., Cohen, E. C., McNulty, S. G., Aldridge, H. D., and Zhang, Y.: Divergence of ecosystem services in US National Forests and Grasslands under a changing climate, Sci Rep-Uk, 6, 2016.

Federer, C. A. and Lash, D.: Simulated streamflow response to possible differences in transpiration among species of hardwood trees, Water Resour. Res., 14, 1089-1097, 1978a.

Federer, C. A. and Lash, D.: Brook: a hydrologic simulation model for eastern forested, Water Resources Reserch Center. University of New Hampshire, Durham, NH, Research Report 19, p. 84, $1978 b$.

Fossey, M. and Rousseau, A. N.: Can isolated and riparian wetlands mitigate the impact of climate change on watershed hydrology? A case study approach, J. Environ. Manage., 184, 327-339, 2016.

Grayson, R. B., Moore, I. D., and McMahon, T. A.: Physically based hydrologic modeling: 1. A terrain-based model for investigative purposes, Water Resour. Res., 28, 2639-2658, 1992.

Greenberg, C., Zarnoch, S., and Austin, J.: Weather, hydroregime, and breeding effort influence juvenile recruitment of anurans: implications for climate change, Ecosphere, 8, https://doi.org/10.1002/ecs2.1789, 2017.

Greenberg, C. H., Goodrick, S., Austin, J. D., and Parresol, B. R.: Hydroregime Prediction Models for Ephemeral GroundwaterDriven Sinkhole Wetlands: a Planning Tool for Climate Change and Amphibian Conservation, Wetlands, 35, 899-911, 2015.

Hammack, J. and Brown Jr., G. M.: Waterfowl and wetlands: Toward bioeconomic analysis, Routledge, 2016.

Hamon, W. R.: Computation of direct runoff amounts from storm rainfall, International Association of Scientific Hydrology Publication, 63, 52-62, 1963.

Hargreaves, G. H. and Samani, Z. A.: Estimating potential evapotranspiration, J. Irr. Drain. Div.-ASCE, 108, 225-230, 1982.

Hefting, M., Clément, J. C., Dowrick, D., Cosandey, A. C., Bernal, S., Cimpian, C., Tatur, A., Burt, T. P., and Pinay, G.: Water table elevation controls on soil nitrogen cycling in riparian wetlands along a European climatic gradient, Biogeochemistry, 67, 113$134,2004$. 
Hessami, M., Gachon, P., Ouarda, T. B. M. J., and St-Hilaire, A.: Automated regression-based statistical downscaling tool, Environ. Modell. Softw., 23, 813-834, 2008.

House, A. R., Thompson, J. R., and Acreman, M. C.: Projecting impacts of climate change on hydrological conditions and biotic responses in a chalk valley riparian wetland, J. Hydrol., 534, 178192, 2016.

IPCC: Climate Change 2014: Synthesis Report. Contribution of Working Groups I, II and III to the Fifth Assessment Report of the Intergovernmental Panel on Climate Change, Report No. 9291691437, IPCC, Geneva, Switzerland, 2014.

Johnston, S. G., Slavich, P. G., and Hirst, P.: Opening floodgates in coastal floodplain drains: effects on tidal forcing and lateral transport of solutes in adjacent groundwater, Agr. Water Manage., 74, 23-46, 2005.

Keellings, D.: Evaluation of downscaled CMIP5 model skill in simulating daily maximum temperature over the southeastern United States, Int. J. Climatol., 36, 4172-4180, 2016.

Klein Tank, A., Wijngaard, J., Können, G., Böhm, R., Demarée, G., Gocheva, A., Mileta, M., Pashiardis, S., Hejkrlik, L., and KernHansen, C.: Daily dataset of 20th-century surface air temperature and precipitation series for the European Climate Assessment, Int. J. Climatol., 22, 1441-1453, 2002.

Kumar, R., Samaniego, L., and Attinger, S.: Implications of distributed hydrologic model parameterization on water fluxes at multiple scales and locations, Water Resour. Res., 49, 360-379, 2013

Li, J. Z., Zhou, S. H., and Hu, R.: Hydrological Drought Class Transition Using SPI and SRI Time Series by Loglinear Regression, Water Resour. Manag., 30, 669-684, 2016.

Li, L. F. and Li, W. H.: Thermodynamic and dynamic contributions to future changes in regional precipitation variance: focus on the Southeastern United States, Clim. Dynam., 45, 67-82, 2015.

Li, L. F., Li, W. H., and Deng, Y.: Summer rainfall variability over the Southeastern United States in the 21st century as assessed by the CMIP5 Models, J. Geophys. Res.-Atmos., 118, 340-354, 2013.

Liu, G., Yang, Z., Tang, Y., and Ulgiati, S.: Spatial correlation model of economy-energy-pollution interactions: The role of river water as a link between production sites and urban areas, Renew. Sust. Energ. Rev., 69, 1018-1028, 2017.

Liu, Y. L. and Kumar, M.: Role of meteorological controls on interannual variations in wet-period characteristics of wetlands, Water Resour. Res., 52, 5056-5074, 2016.

Lu, J. B.: Modeling Hydrologic Responses to Forest Management and Climate Change in Contrasting Watersheds in the Southeastern United States, PhD thesis, North Carolina State University, Raleigh, 2006.

Lu, J. B., Sun, G., McNulty, S. G., and Comerford, N. B.: Sensitivity of Pine Flatwoods Hydrology to Climate Change and Forest Management in Florida, USA, Wetlands, 29, 826-836, 2009.

Lyman, R. A.: Peak and off-peak residential water demand, Water Resour. Res., 28, 2159-2167, 1992.

Manoli, G., Domec, J. C., Novick, K., Oishi, A. C., Noormets, A., Marani, M., and Katul, G.: Soil-Plant-Atmosphere Conditions Regulating Convective Cloud Formation Above Southeastern US Pine Plantations, Glob. Change Biol., 22, 2238-2254, 2016.
Medvedeff, C. A., Inglett, K. S., and Inglett, P. W.: Can Fire Residues (Ash and Char) Affect Microbial Decomposition in Wetland Soils?, Wetlands, 35, 1165-1173, 2015.

Meinshausen, M., Smith, S. J., Calvin, K., Daniel, J. S., Kainuma, M. L. T., Lamarque, J. F., Matsumoto, K., Montzka, S. A., Raper, S. C. B., Riahi, K., Thomson, A., Velders, G. J. M., and van Vuuren, D. P. P.: The RCP greenhouse gas concentrations and their extensions from 1765 to 2300, Climatic Change, 109, 213-241, 2011.

Miao, G. F.: A Multi-scale Study on Respiratory Processes in a Lower Coastal Plain Forested Wetland in the Southeastern United States, PhD thsis, North Carolina State University, Raleigh, 2013.

Miao, G. F., Noormets, A., Domec, J. C., Trettin, C. C., McNulty, S. G., Sun, G., and King, J. S.: The effect of water table fluctuation on soil respiration in a lower coastal plain forested wetland in the southeastern US, J. Geophys. Res.-Biogeo., 118, 1748-1762, 2013.

Mills, T. C.: Time Series Techniques for Economists, Cambridge University Press, 1990.

Mitchell, R. J., Liu, Y., O’Brien, J. J., Elliott, K. J., Starr, G., Miniat, C. F., and Hiers, J. K.: Future climate and fire interactions in the southeastern region of the United States, Forest Ecol. Manag., 327, 316-326, 2014.

Moor, H., Hylander, K., and Norberg, J.: Predicting climate change effects on wetland ecosystem services using species distribution modeling and plant functional traits, Ambio, 44, S113-S126, 2015.

Moore, T. and Knowles, R.: The influence of water table levels on methane and carbon dioxide emissions from peatland soils, Can. J. Soil. Sci., 69, 33-38, 1989.

Moorhead, K. K. and Brinson, M. M.: Response of wetlands to rising sea level in the lower coastal plain of North Carolina, Ecol. Appl., 5, 261-271, 1995.

Mulhouse, J. M., De Steven, D., Lide, R. F., and Sharitz, R. R.: Effects of dominant species on vegetation change in Carolina bay wetlands following a multi-year drought, J. Torrey Bot. Soc., 132, 411-420, 2005.

Murphy, C. M., Tuberville, T. D., Maerz, J. C., and Andrews, K. M.: Evaporative Water Loss Rates of Four Species of Aquatic Turtles from the Coastal Plain of the Southeastern United States, J. Herpetol., 50, 457-463, 2016.

Nelms, K. D.: Wetland management for waterfowl handbook, Mississippi River Trust, Stoneville, Mississippi, USA, 2007.

Nicholls, R. J.: Coastal flooding and wetland loss in the 21 st century: changes under the SRES climate and socio-economic scenarios, Global Environ. Chang., 14, 69-86, 2004.

Noormets, A., McNulty, S. G., DeForest, J. L., Sun, G., Li, Q., and Chen, J.: Drought during canopy development has lasting effect on annual carbon balance in a deciduous temperate forest, New Phytol., 179, 818-828, 2008.

Noormets, A., Gavazzi, M. J., McNulty, S. G., Domec, J.-C., Sun, G. E., King, J. S., and Chen, J.: Response of carbon fluxes to drought in a coastal plain loblolly pine forest, Glob. Change Biol., 16, 272-287, 2010.

Osland, M. J., Enwright, N., Day, R. H., and Doyle, T. W.: Winter climate change and coastal wetland foundation species: salt marshes vs. mangrove forests in the southeastern United States, Glob. Change Biol., 19, 1482-1494, 2013. 
Ozturk, I.: Sustainability in the food-energy-water nexus: Evidence from BRICS (Brazil, the Russian Federation, India, China, and South Africa) countries, Energy, 93, 999-1010, 2015.

Pachauri, R. K., Allen, M. R., Barros, V., Broome, J., Cramer, W., Christ, R., Church, J., Clarke, L., Dahe, Q., and Dasgupta, P.: Climate change 2014: synthesis Report. Contribution of working groups I, II and III to the fifth assessment report of the intergovernmental panel on climate change, IPCC, 2014.

Paschalis, A., Katul, G. G., Fatichi, S., Palmroth, S., and Way, D.: On the variability of the ecosystem response to elevated atmospheric $\mathrm{CO}_{2}$ across spatial and temporal scales at the Duke Forest FACE experiment, Agr. Forest Meteorol., 232, 367-383, 2017.

Pokhrel, P., Gupta, H. V., and Wagener, T.: A spatial regularization approach to parameter estimation for a distributed watershed model, Water Resour. Res., 44, https://doi.org/10.1029/2007WR006615, 2008.

Pyzoha, J. E., Callahan, T. J., Sun, G., Trettin, C. C., and Miwa, M.: A conceptual hydrologic model for a forested Carolina bay depressional wetland on the Coastal Plain of South Carolina, USA, Hydrol. Process., 22, 2689-2698, 2008.

Qu, Y. and Duffy, C. J.: A semidiscrete finite volume formulation for multiprocess watershed simulation, Water Resour. Res., 43, W08419, https://doi.org/10.1029/2006WR005752, 2007.

Reddy, K. R. and DeLaune, R. D.: Biogeochemistry of wetlands: science and applications, CRC press, 2008.

Richardson, C. J.: Ecological Functions and Human-Values in Wetlands-a Framework for Assessing Forestry Impacts, Wetlands, 14, 1-9, 1994.

Sachindra, D. A., Huang, F., Barton, A., and Perera, B. J. C.: Least square support vector and multi-linear regression for statistically downscaling general circulation model outputs to catchment streamflows, Int. J. Climatol., 33, 1087-1106, 2013.

Schlesinger, W. H., Dietze, M. C., Jackson, R. B., Phillips, R. P., Rhoades, C. C., Rustad, L. E., and Vose, J. M.: Forest biogeochemistry in response to drought, Glob. Change Biol., 22, 2318 2328, 2016.

Shen, C. and Phanikumar, M. S.: A process-based, distributed hydrologic model based on a large-scale method for surfacesubsurface coupling, Adv. Water Resour., 33, 1524-1541, 2010.

Shindell, D. T., Walter, B. P., and Faluvegi, G.: Impacts of climate change on methane emissions from wetlands, Geophys. Res. Lett., 31, L21202, https://doi.org/10.1029/2004GL021009, 2004.

Sun, G., Riekerk, H., and Comerford, N. B.: Modeling the forest hydrology of wetland-upland ecosystems in Florida, J. Am. Water Resour. As., 34, 827-841, 1998.

Sun, G., Riekerk, H., and Kornhak, L. V.: Ground-water-table rise after forest harvesting on cypress-pine flatwoods in Florida, Wetlands, 20, 101-112, 2000.

Sun, G., McNulty, S. G., Amatya, D. M., Skaggs, R. W., Swift, L. W., Shepard, J. P., and Riekerk, H.: A comparison of the watershed hydrology of coastal forested wetlands and the mountainous uplands in the Southern US, J. Hydrol., 263, 92-104, 2002.

Sun, G., Callahan, T. J., Pyzoha, J. E., and Trettin, C. C.: Modeling the climatic and subsurface stratigraphy controls on the hydrology of a Carolina bay wetland in South Carolina, USA, Wetlands, 26, 567-580, 2006.
Sun, G., Noormets, A., Gavazzi, M. J., McNulty, S. G., Chen, J., Domec, J. C., King, J. S., Amatya, D. M., and Skaggs, R. W.: Energy and water balance of two contrasting loblolly pine plantations on the lower coastal plain of North Carolina, USA, Forest Ecol. Manag., 259, 1299-1310, 2010.

Tian, S. Y., Youssef, M. A., Skaggs, R. W., Amatya, D. M., and Chescheir, G. M.: Modeling water, carbon, and nitrogen dynamics for two drained pine plantations under intensive management practices, Forest Ecol. Manag., 264, 20-36, 2012.

Tian, S. Y., Youssef, M. A., Sun, G., Chescheir, G. M., Noormets, A., Amatya, D. M., Skaggs, R. W., King, J. S., McNulty, S., Gavazzi, M., Miao, G. F., and Domec, J. C.: Testing DRAINMOD-FOREST for predicting evapotranspiration in a mid-rotation pine plantation, Forest Ecol. Manag., 355, 37-47, 2015.

Tiner, R. W.: Wetland indicators: a guide to wetland identification, delineation, classification, and mapping, 2nd Edn., CRC Press, 2016.

United States Naval Observatory: available at: http://aa.usno.navy. mil/data/docs/Dur_OneYear.php, last access: 29 October 2017.

Vivoni, E. R., Mascaro, G., Mniszewski, S., Fasel, P., Springer, E. P., Ivanov, V. Y., and Bras, R. L.: Real-world hydrologic assessment of a fully-distributed hydrological model in a parallel computing environment, J. Hydrol., 409, 483-496, 2011.

Vose, J. M., Miniat, C. F., Luce, C. H., Asbjornsen, H., Caldwell, P. V., Campbell, J. L., Grant, G. E., Isaak, D. J., Loheide, S. P., and Sun, G.: Ecohydrological implications of drought for forests in the United States, Forest Ecol. Manag., 380, 225-345, 2016.

Wang, H., Fu, R., Kumar, A., and Li, W. H.: Variability and Predictability of Southeastern United States Summer Precipitation, J. Hydroclim., 11, 1007-1018, 2010.

Wang, X. Y., Yang, T., Krysanova, V., and Yu, Z. B.: Assessing the impact of climate change on flood in an alpine catchment using multiple hydrological models, Stoch. Env. Res. Risk A., 29, 2143-2158, 2015.

Webb, B., Clack, P., and Walling, D.: Water-air temperature relationships in a Devon river system and the role of flow, Hydrol. Process., 17, 3069-3084, 2003.

Webb, R. H. and Leake, S. A.: Ground-water surface-water interactions and long-term change in riverine riparian vegetation in the southwestern United States, J. Hydrol., 320, 302-323, 2006.

Westerling, A. L., Hidalgo, H. G., Cayan, D. R., and Swetnam, T. W.: Warming and earlier spring increase western US forest wildfire activity, Science, 313, 940-943, 2006.

Wuebbles, D., Meehl, G., Hayhoe, K., Karl, T. R., Kunkel, K., Santer, B., Wehner, M., Colle, B., Fischer, E. M., and Fu, R.: CMIP5 climate model analyses: climate extremes in the United States, B. Am. Meteorol. Soc., 95, 571-583, 2014.

Yu, X., Gopal, B., Christopher, J. D., Denice, H. W., Raymond, G. N., Andrew, C. W., and Matthew, R.: A coupled surface subsurface modeling framework to assess the impact of climate change on freshwater wetlands, Clim. Res., 66, 211-228, 2015. 